\title{
KLASSIFIKASI BAHAN ORGANIK TANAH BUKIT PINANG-PINANG KAWASAN HUTAN HUJ AN TROPIK GUNUNG GADUT PADANG
}

\author{
Yulnafatmawita, Asmar, Mimin Haryanti, dan Suci Betrianingrum \\ Laboratorium Fisika Tanah Fakultas Pertanian U nand Padang
}

\begin{abstract}
A research about soil organic matter (SOM) classification based on the density was conducted for soil in Bukik Pinang-Pinang region. The objective of this research was to identify whether the SOM in Pinang-Pinang area, having very high annual rainfall, was mostly particulate or had been associated with mineral particles. Soils were sampled at three different land use, forest, bush, and mixed wood land on 0-10, 10-20, and 20-30 cm soil depth. Soil organic matter was classified into 2 classes, $<1.0 \mathrm{~g} \mathrm{~cm}^{-3}$ and $\geq 1.0 \mathrm{~g} \mathrm{~cm}^{-3}$ by using pure aquadest. Total and fractionated SOM samples were analyzed by using Walkley and Black method in soil laboratory, Agriclculture College, Andalas University. The result showed that, among the three land use surveyed, mixed wood land use gave the highest SOM, then followed by bush land. Soil OM content in forest ecosystem was much lower than the other two land use for the whole depth. Based on the density, SOM particulate was higher on the soil surface and decrease by depth in each land use. Among the ecosystem, SOM under forest was less associated with soil particles than that under bush and mixed wood land.
\end{abstract}

Key Words: SOM -light fraction, SOM -heavy fraction, land use

\section{PENDAHULUAN}

Keberadaan bahan organik tanah
merupakan suatu keharusan untuk
menciptakan pertanian berkelanjutan dan
kelestarian lingkungan. Hal ini disebabkan
karena bahan organik berperan penting
dalam menciptakan kesuburan tanah, baik
secara fisika, kimia, maupun biologi tanah.
Bahan organik tanah tersebut bersumber dari
jaringan tumbuhan dan hewan yang berada
di atas ataupun di dalam tanah itu sendiri. Berbeda sumber bahan organik tanah tersebut akan berbeda pula pengaruh yang akan disumbangkanya ke dalam tanah. Hal ini berkaitan dengan komposisi atau susunan dari bahan organik tersebut.

Bahan organik dapat memperbaiki sifat fisika tanah diantaranya dapat membentuk dan meningkatkan stabilitas agregat bila persentasenya cukup di dalam tanah. Struktur tanah yang bagus dan agregat yang stabil meningkatkan retensi dan transmisi air, memperbaiki drainase dan aerase tanah menyeimbangkan udara dan air dalam pori tanah sehingga mampu menciptakan kondisi zona pertumbuhan akar tanaman yang baik. Selanjutnya, kondisi tanah demikian memudahkan pengolahan tanah dan menciptakan lingkungan yang baik bagi pertumbuhan tanaman. Disamping itu, bahan organik juga dapat meningkatkan suplai air untuk kebutuhan tanaman, karena bahan organik dapat menyerap dan menyimpan air melebihi beratnya sendiri.

Kandungan bahan organik tanah bersifat dinamik, berubah dengan waktu dan ruang. Pengolahan tanah yang berlebihan dalam budidaya tanaman akan mempengaruhi keberadaan bahan organik di dalam tanah. Jika tanah selalu diolah tanpa penambahan bahan organik secara regular pada suatu lahan, maka kandungan bahan organik di dalam tanah semakin lama akan semakin berkurang akibat terjadinya oksidasi bahan organik. Hal ini akan mengakibatkan degradasi pada struktur tanah, agregat tanah mudah terdispersi, laju infiltrasi rendah, run off meningkat sehingga tanah mudah mengalami erosi. Lahan yang digunakan untuk kegiatan pertanian terutama untuk tanaman semusim sering menurunkan kualitas atau tingkat kesuburan tanah, bila praktek pertanian ini tidak memperdulikan kaidah konservasi tanah.

Kehilangan bahan organik tanah akibat pengolahan tanah diawali oleh teroksidasinya BO particulate atau dikenal 
juga dengan bahan organik fraksi ringan (Christensen, 1992). Dengan kata lain, BO particulate ini disebut juga dengan $\mathrm{BO}$ yang masih lepas atau yang belum berasosiasi dengan tanah. Jika diukur berat BO particulate ini persatuan volumenya (BJ nya), maka nilainya akan lebih rendah dari BO yang sudah berasosiasi dengan tanah. Tidak berasosiasinya $\mathrm{BO}$ particulate ini dengan tanah mengakibatkan $\mathrm{BO}$ ini mudah dijangkau dan diokasidasi secara enzimatik oleh mikroba (Dalal dan Meyer, 1986).

Bahan organik fraksi berat, disisi lain, merupakan $\mathrm{BO}$ yang sudah berasosiasi dengan tanah dan mempunyai $\mathrm{BJ}$ yang lebih tinggi dari BO particulate. Bahan organik ini berada dalam pori mikro tanah, atau terlindung secara fisik dalam aggregat tanah, yang tidak mampu ditembus oleh mikroba. Bahan organik ini baru akan mengalami oksidasi atau dapat diserang mikroba setelah terjadi pengolahan tanah. Yulnafatmawita et al (2003) mendapatkan bahwa meningkatnya intensitas pengolahan tanah, maka meningkat pula jumlah BO yang bisa dioksidasi oleh mikroba. Hal ini terbukti dengan meningkatnya jumlah $\mathrm{CO} 2$ hasil dekomposisi BO yang diemisikan dari tanah yang didegradasi dengan energi yang lebih tinggi.

Menurut Christensen (1992), BO fraksi ringan terbentuk dari sisa dekomposisi tanaman dan binatang dengan $\mathrm{C} / \mathrm{N}$ yang masih tinggi, siklus perputaran yang cepat, spesifik densitas yang lebih rendah dari mineral tanah. Sedangkan BO fraksi berat termasuk kedalamnya kompleks organomineral, yaitu bahan organik tanah yang berasal dari hasil proses dekomposisi dengan rasio $\mathrm{C} / \mathrm{N}$ yang kecil, proses dekomposisi lebih lambat, densitas spesifik lebih tinggi karena adanya asosiasi dengan mineral tanah.

Hilangnya bahan organik tanah, disamping pengolahan tanah, juga sering terjadi akibat alih fungsi lahan, dari lahan hutan menjadi lahan pertanian atau lahan non pertanian lainnya. Hal ini akan sangat terasa bila terjadi pada hulu suatu daerah aliran sungai (DAS). Daerah hulu yang terbuka akan mempercepat proses pelapukan dan kehilangan bahan organiknya. Tanah dengan $\mathrm{BO}$ yang rendah akan menyebabkan mudahnya aggregat terdegradasi, apalagi di bawah curah hujan yang tinggi. Aggregat yang pecah bahkan sampai terdispersi menjadi butir tunggal akan menyumbat pori tanah, sehingga laju masuknya air ke dalam tanah (infiltrasi) akan menurun, dan sebagian besar $\mathrm{CH}$ yang diterima akan mengalir di permukaan tanah (runoff) dan masuk ke sungai. Ada kalanya, pada intensitas hujan yang sangat tinggi, sungai tak mampu menampung semua air yang masuk sehingga harus meluapkan airnya yang berakibat pada terjadinya banjir di daerah hilir. Dengan demikian, fungsi hutan sebagai penyerap dan penyimpan $\mathrm{CH}$ serta mengeluarkannya sedikit demi sedikit sepanjang tahun akan berkurang atau hilang.

Bukit Pinang-Pinang adalah salah satu kawasan hutan hujan tropis yang berlokasi di Padang Sumatra Barat dan merupakan kaki Gunung Gadut bagian atas, terletak pada ketinggian antara $\pm 400-650 \mathrm{~m}$ dpl. Daerah ini merupakan daerah unik karena merupakan daerah penerima curah hujan tertinggi, mencapai $6500 \mathrm{~mm} / \mathrm{tahun}$ (Rasyidin, 1994), dan mempunyai keragaman tanaman yang tinggi. Kawasan ini dilintasi oleh 2 sungai yaitu sungai Gadut Gadang dan sungai Batang Lantiak. Kedua sungai ini akan mengalirkan airnya ke sungai Batang Kuranji yang melintasi kota Padang sebelum sampai di laut. Oleh sebab itu, area Pinang-Pinang ini perlu dikonservasi untuk mempertahankan fungsinya sebagai pengatur hidrologi. Hal ini sangat penting untuk mengantisipasi bencana alam, kebanjiran dan longsor pada musim hujan dan kekeringan dimusim panas pada daerah alirannya, seperti yang sudah menimpa kebanyakan daerah-daerah lain di negara tercinta ini.

Saat ini kawasan hutan di kaki Gunung Gadut ini sudah tidak utuh lagi, ada yang sudah berubah menjadi kebun campuran dan ada yang menjadi semak belukar. Kebun campuran ditemukan pada bagian kaki bukit Pinang Pinang, diperkirakan hutan ini sudah dibuka sejak beberapa dekade yang lalu. Sedangkan semak belukar ditemukan di pinggang bukit. Dengan berubahnya kondisi penggunaan lahan pada daerah ini diperkirakan akan mempengaruhi keberadaan bahan organik di 
dalam tanah. Dalam usaha memprediksi kehilangan kandungan bahan organik pada beberapa penggunaan lahan di kawasan hutan hujan tropik Gunung Gadut ini, maka salah satu cara yang bisa dilakukan yaitu dengan mengklasifikasikan BO menurut densitasnya. Penelitian ini bertujuan untuk menghitung bahan organik tanah fraksi berat dan fraksi ringan pada tiga penggunaan lahan (hutan, kebun campuran dan semak belukar) dari kawasan hutan hujan tropik Bukit Pinang Pinang Gunung Gadut Padang.

\section{BAHAN DAN METODA}

Penelitian ini dilakukan dari bulan Maret sampai Juli 2007 di Bukit Pinang Pinang kawasan Hutan Hujan Tropis kaki Gunung Gadut Padang. Sampel tanah diambil pada 3 penggunaan lahan (hutan, kebun campuran, dan semak belukar) yang terdapat pada kaki, pinggang, dan puncak bukit. Titik penyampelan ditetapkan pada kemiringan yang paling kecil di masing-masing penggunaan lahan. Sampel tanah pada masing-masing titik penyampelan diambil secara satelit dengan menggunakan bor Belgi pada kedalam 0-10, 10-20, 20-30 dan $\mathrm{cm}$ pada untuk analisis BO dan fraksionasi BO tanah. Kandungan BO tanah dianalisis dengan metoda Walkley dan Black, sedangkan klassifikasi BO dilakukan dengan menggunakan akuades murni yang berdensitas $1 \mathrm{~g} \mathrm{~cm}^{-3}$. Dengan demikian, dalam hal ini BO fraksi ringan akan mempunyai densitas $<1 \mathrm{~g} \mathrm{~cm}^{-3}$ dan fraksi berat $\geq 1 \mathrm{~g} \mathrm{~cm}^{-3}$. Setelah BO dipisahkan menjadi 2 bagian (fraksi ringan (BO-FR) dan BO fraksi berat (BO-FB), dianalisis kandungan $\mathrm{C}$-organik masing-masing bagian dengan metoda Walkley dan Black. Jumlah percentase BO-FR dengan BO-FB akan sama dengan jumlah total $\mathrm{BO}$ tanah.

\section{HASIL DAN PEMBAHASAN}

\section{Sejarah Penggunaan Lahan}

Dari hasil survai di lapangan diperoleh bahwa terdapat tiga penggunaan lahan yaitu hutan, kebun campuran, dan semak belukar pada kawasan Bukit Pinang Pinang, hutan hujan tropis kaki gunung Gadut ini. Hutan pada kawasan ini telah banyak ditebang secara liar, sehingga pohon-pohon yang berdiameter besar sudah mulai jarang ditemui. Akan tetapi ciri-ciri hutan masih ditemukan di kawasan ini, selain masih terdapat pepohonan yang berkanopi cukup rapat juga masih ditemukan sarasah yang cukup tebal $( \pm 5 \mathrm{~cm}$ dari permukaan tanah). Disamping itu, cahaya matahari tidak mencapai permukaan tanah karena terhalang oleh rindangnya pepohonan yang ada pada kawasan ini.

Hutan Pinang Pinang ini sangat kaya dengan spesies tanaman. Tanaman yang tumbuh bukan hanya dalam bentuk pohon tetapi juga tanaman merambat (memanjat). Menurut Wakatsuki dan Rasyidin (1994 cit Aflizar, 2003) ada \pm 892 spesies tanaman yang dijumpai di hutan ini, dan 231 spesies sudah teridentifikasi. Tanaman inilah yang akan menyumbangkan bahan organik terhadap tanahnya.

Berdasarkan peta penggunaan lahan (Hasil Interpretasi Peta Topografi JANTOP TNI AD, 1984. Skala 1: 20.000, helai 1323-II) kawasan lahan hutan ukurannya paling luas diantaranya yaitu \pm $62,59 \mathrm{Ha}(63,45 \%)$ dari keseluruhan luas bukit Pinang Pinang, 


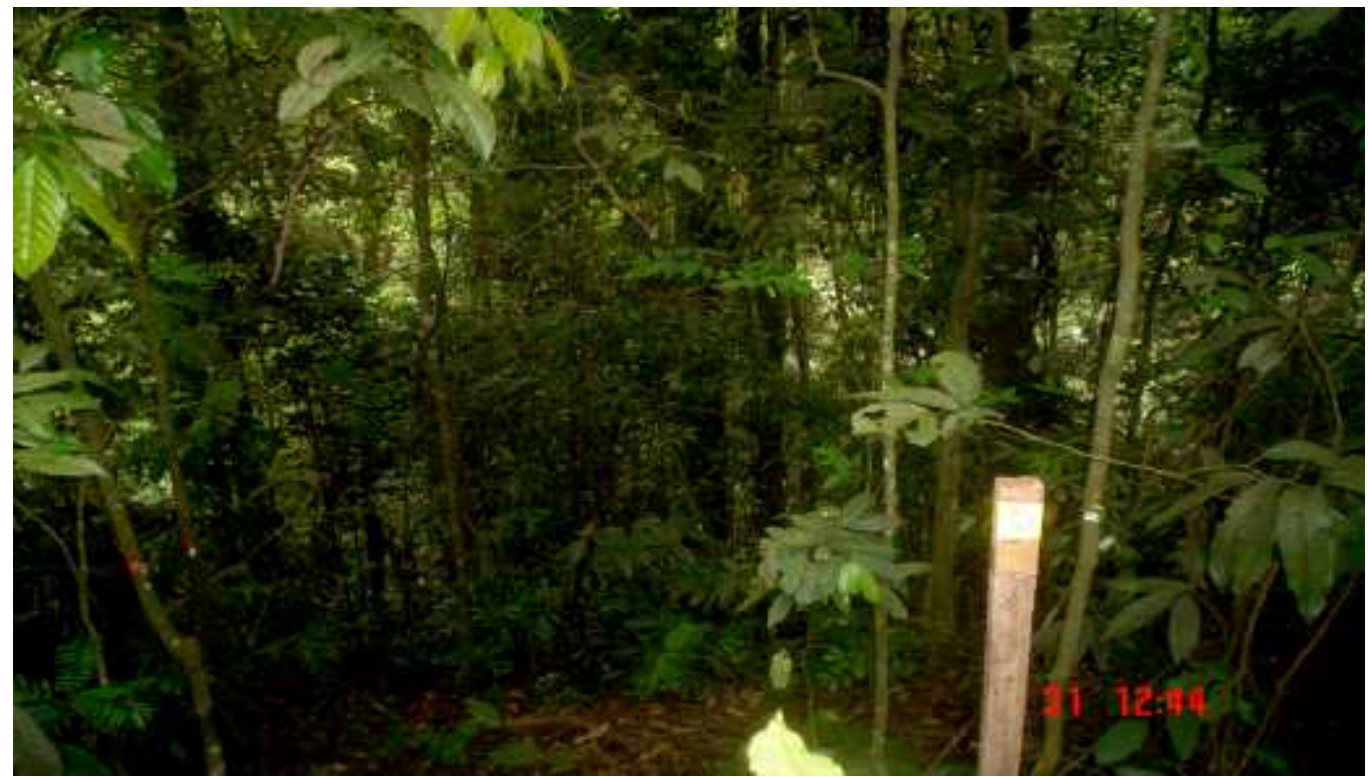

Gambar 1. Hutan di Bukit Pinang Pinang kawasan hutan hujan tropik Gunung Gadut

terdapat dibagian pinggang dan puncak Bukit. Kebun campuran hanya ditemui di kaki bukit dengan luas $14,05 \mathrm{Ha}( \pm 14,36 \%)$, dan semak belukar dengan luas $21,23 \mathrm{Ha}( \pm$ $21,69 \%$ ) ditemui di pinggang bukit. Gambar masing-masing kondisi lahan ditampilkan pada Gambar 1, 2, dan 3.

Dari Gambar 1 terlihat bahwa pohon yang ada pada hutan ini kebanyakan masih kecil, karena sudah terjadi tebang pilih. Namun, semenjak tahun 1980-an lokasi ini sudah diplot sebagai hutan penelitian Universitas Andalas dan dinyatakan dilindungi. Bukan saja para peneliti Unand yang datang, tetapi dunia international juga melirik ke daeah ini, seperti Jepang. Jepang sudah melakukan penelitian di puncak bukit Pinang-Pinang ini semenjak tahun 1980-an yang lalu.

Akan tetapi, lahan yang dijadikan kebun campuran pada umumnya adalah lahan yang ditinggalkan setelah penebangan sekitar 50 tahunan yang lalu. Lahan ini terdapat di kaki bukit, mempunyai kemiringan 3\% hingga 8\%. Di samping tanaman pisang (Musa, sp) yang bisa dipanen penduduk setiap tahunnya, areal ini pada umumnya ditanami pohon manggis (Garcinia mangostana, L), durian (Durio zibetinus), kulit manis (Cinnamomum burmanii) dan coklat (Theobroma cacao, L).
Pohon-pohon ini sudah cukup tua-tua, hal ini terlihat dari diameter tanaman yang sudah besar.

Disamping ditanami dengan tanaman budidaya yang berproduksi, tanah pada lahan ini juga ditumbuhi oleh tumbuhan liar yang tumbuh secara alami dipermukaan tanah. Vegetasi yang tumbuh pada lahan ini didominasi oleh rumputrumputan dan krinyuh (Caladium surinameuse). Dengan demikian, permukaan lahan tidak ada yang terbuka atau dengan kata lain tanaman liar yang tumbuh berperan sebagai cover crop (Gambar 2). Tanaman penutup tanah ini dipotong oleh petani pngusahanya secara reguler, terutama ketika musim buah tiba. Oleh sebab itu, sumbangan BO terhadap tanahnya cukup banyak.

Hampir sama dengan kebun campuran, lahan semak yang terdapat di sebagian pinggang bukit juga ditutupi oleh tumbuhan, terutama tumbuhan perdu dan merambat (Gambar 3). Lahan semak ini banyak terdapat pada lahan-lahan bekas penebangan hutan yang relatif masih baru, tetapi tidak memungkinkan untuk dijadikan kebun karena pada umumnya terletak pada lereng yang curam $(\geq 40 \%)$. Tanah tersebut ditinggalkan terbuka, sehingga ditumbuhi oleh semak dan mampu menutupi 


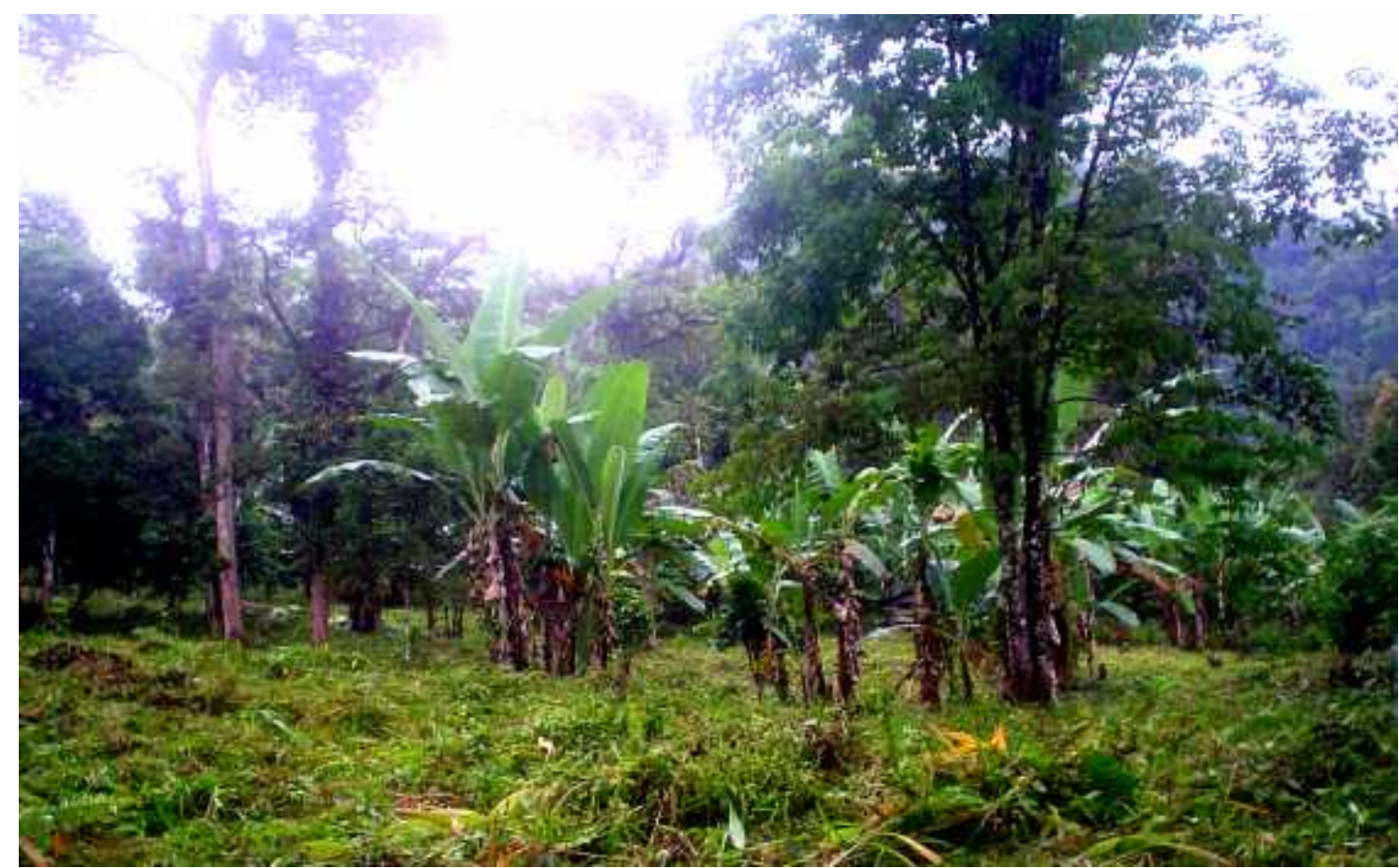

Gambar 2. Kebun Campuran di Bukit Pinang Pinang kawasan hutan hujan tropik Gunung Gadut

permukaan tanah. Tumbuhan yang terdapat pada lahan semak ini diantaranya krinyuh (Caladium surinameuse), jelatang, sikaduduak (Melastoma malabatricum), paku resam (Gleicenia linearis), linju, pandan, rimbang dan lainnya.

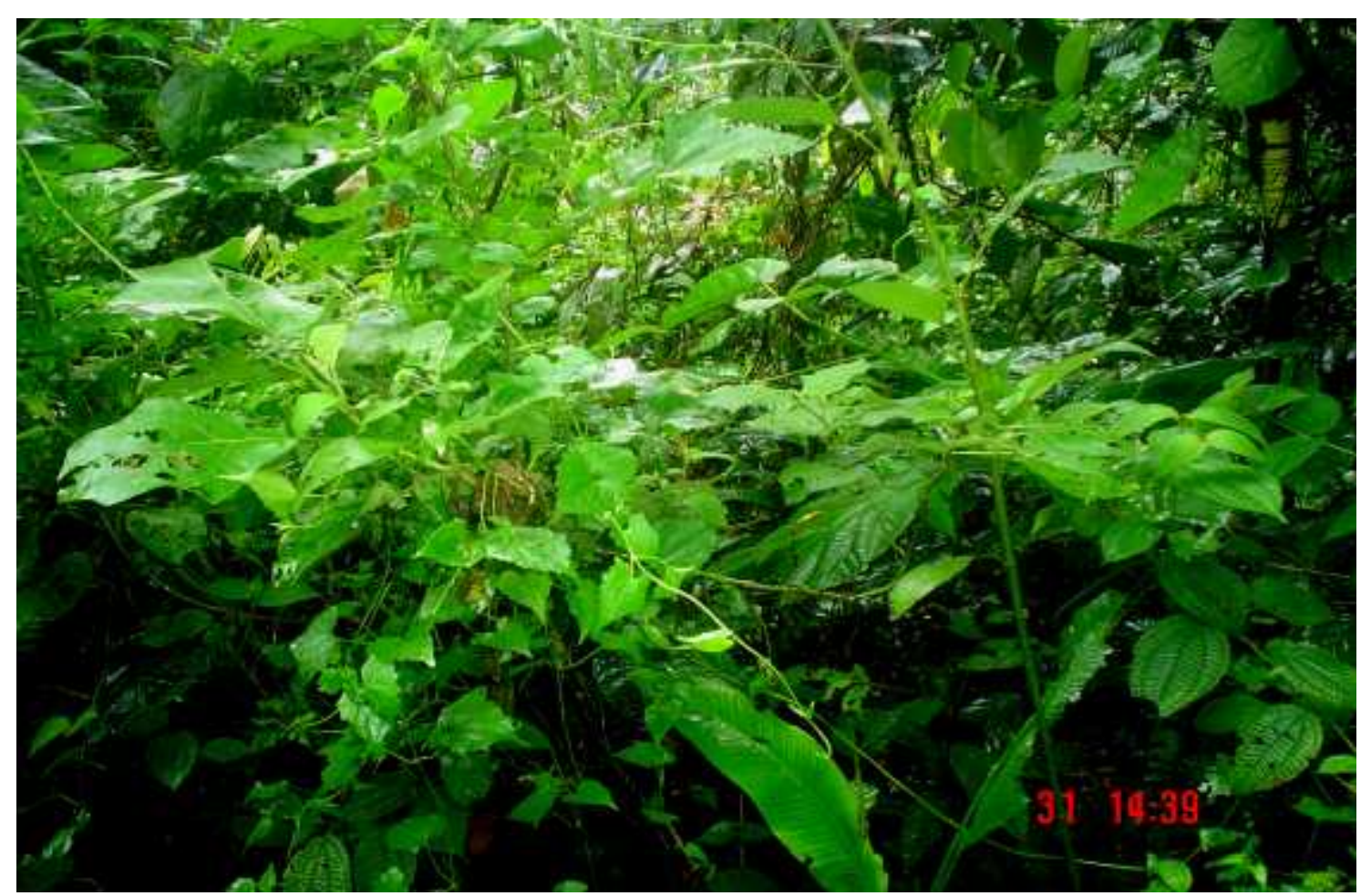

Gambar 3. Semak Belukar di Bukit Pinang Pinang kawasan hutan hujan

tropik Gunung Gadut 
Kandungan Bahan Organik Tanah

Tabel 1. Kandungan bahan organik tanah pada 3 penggunaan lahan di kawasan hutan hujan tropik Pinang Pinang.

\begin{tabular}{lccc}
\hline Penggunaan & \multicolumn{3}{c}{ Kedalaman } \\
\cline { 2 - 4 } Lahan & $0-10$ & $10-20$ & $20-30$ \\
\hline \multirow{2}{*}{ Hutan } & ---------------- & $------\%$ BO------ & ------------- \\
Semak Belukar & $2.76(\mathrm{r})$ & $1.42(\mathrm{sr})$ & $1.14(\mathrm{sr})$ \\
Kebun Campuran & $3.50(\mathrm{~s})$ & $2.26(\mathrm{r})$ & $1.89(\mathrm{sr})$ \\
\hline
\end{tabular}

Hasil rata-rata kandungan bahan organik tanah total yang terdapat dibawah penggunaan lahan di kawasan penelitian ditampilkan pada Tabel 1 diatas dan grafiknya dapat dilihat pada Gambar 4.

Dari Tabel 1 dapat dilihat bahwa alih fungsi lahan dari lahan hutan menjadi kebun campuran atau pun menjadi semak belukar tidak menurunkan kandungan bahan organik tanah, bahkan kandungan bahan organik tanah meningkat setelah beberapa dekade pembabatan hutan. Kandungan bahan organik tanah pada kebun campuran ( \pm 50 tahun setelah pembukaan hutan) termasuk kriteria sedang atau lebih tinggi dibandingkan semak belukar dan hutan. Hal ini dapat disebabkan pada beberapa hal, diantaranya sumber bahan organik dan lingkungan mikro tanahnya.

Penggunaan lahan yang berbeda akan menyumbangkan jenis dan jumlah bahan organik segar yang berbeda pada tanahnya. Hal ini dapat dipengaruhi oleh vegetasi yang tumbuh pada masing-masing lahan. Yulnafatmawita (2004) menyampaikan bahwa dari tanah Oxisol yang ditumbuhi hutan dan padang rumput yang bersebelahan memberikan kandugan BO yang berbeda. Hal ini disebabkan bukan hanya oleh jenis vegetasi sebagai penyumbang $\mathrm{BO}$ yang berbeda, tetapi juga tipe, jumlah, dan akifitas mikroba perombak BO dari masing-masing lahan.

Pada lahan hutan walaupun sumber bahan organiknya banyak, tetapi bahan organik yang disumbangkan ke dalam tanah tidak banyak. Hal ini disebabkan karena proses pelapukan bahan organik pada lahan hutan termasuk lambat atau bahan organiknya sukar melapuk. Bahan organik yang jatuh menumpuk pada permukaan tanah membentuk lapisan sarasah yang tebal, hal ini dapat dipengaruhi oleh lingkungan mikro di dalam hutan khususnya antara permukaan tanah dan kanopi tanaman. Daerah ini mempunyai suhu yang lebih rendah dan kelembaban yang lebih tinggi dibanding daerah luarnya. Disamping itu, kurang atau tidak adanya cahaya yang masuk mengakibatkan rendahnya aktifitas mikroba dalam merombak bahan organik. Hal ini dapat dilihat pada warna tanahnya yang merah kekuningan, menunjukan kurangnya bahan organik, walaupun serasahnya cukup tebal.

Kondisi fisik tanah yang hampir sama dengan lahan hutan, yaitu mempunyai tekstur halus, ditemui pada lahan semak belukar. Akan tetapi, kandungan BO tanahnya (termasuk kriteria sedang) \pm $26.8 \%, 59.2 \%$, dan $65.8 \%$ lebih tinggi dibanding lahan hutan pada ke dalaman 0-10, 10-20, dan 20-30 cm secara berturut-turut. Hal ini disebabkan karena pada lahan semak walaupun sumber bahan organiknya tidak banyak tetapi proses pelapukannya relatif lebih cepat dibandingkan pada lahan hutan karena lingkungannya cukup kondusif bagi aktifitas mikroba perombak. Disamping itu, jenis tumbuhan perdu yang tumbuh pada lahan semak ini umumnya banyak mengandung air contohnya krinyuh (Caladium surinameuse), sikaduduak (Melastoma malabatricum) sifatnya mudah melapuk dan mempunyai siklus hidup yang lebih pendek dari tanaman tua (tanaman hutan), sehingga dapat cepat 
menyumbangkan bahan organik ke dalam tanah.

Dibanding semak belukar dan hutan, kandungan BO kebun campuran jauh lebih tinggi dan termasuk kriteria sedang. Kandungan BO tanah meningkat sekitar $93.5 \%, 162 \%$, dan $91.2 \%$ dibanding hutan pada ke dalaman 0-10, 10-20, dan 20-30 cm, secara berturut-turut. Hal ini disebabkan terutama oleh sumbangan bahan oraganik dari vegetasi yang tumbuh di atasnya, khususnya tanaman penutup tanah, disamping oleh lingkungan tanah yang hampir sama dengan lahan semak belukar. Bahan organik yang berasal dari tanaman penutup tanah tersebut mengalami dekomposisi yang lebih cepat dibandingkan tanaman pada lahan hutan. Di samping itu, pembabatan tanaman penutup tanah ini secara reguler oleh petani juga mempercepat peningkatan kandungan BO tanah. Tambahan lagi, kondisi lahan yang relatif datar (lereng <8\%) menyebabkan BO yang diproduksi tidak banyak berpindah secara horizontal di permukaan tanah.

Kandungan bahan organik tanah yang lebih tinggi dilapisan $0-20 \mathrm{~cm}$, pada kebun campuran dibanding lahan hutan juga ditemukan di kawasan Bukit Gajabuih, sebelah timur Bukit Pinang Pinang
(Yulnafatmawita et al., 2006) dan begitu juga pada sub DAS Sumpur bagian hulu (Yulnafatmawita et al., 2005). Hal ini mengindikasikan bahwa perubahan lahan hutan menjadi kebun campuran setelah beberapa dekade ( \pm 50 tahunan) dengan mempertahankan permukaan tanah ditutupi vegetasi dapat meningkatkan kandungan bahan organik tanah dari lahan hutan.

Kandungan BO tanah pada setiap penggunaan lahan menurun dengan kedalaman tanah. Hal ini disebabkan karena sumber utama BO tanah berasal dari tumbuhan dan binatang yang ada pada permukaan tanah. Sumbangan akar dan fauna tanah jauh lebih kecil dibanding daun, ranting dan batang. Semakin dalam tanah, semakin rendah persentase akar dan semakin rendah pula aktifitas mikroba. Untuk lebih jelasnya, penurunan kandungan bahan organik dari lapisan $0-10 \mathrm{~cm}$ ke $10-20$ $\mathrm{cm}$ dan $20-30 \mathrm{~cm}$ dapat dilihat pada Gambar 4. Hal ini sesuai dengan pendapat Hakim et al. (1986) menjelaskan bahwa kandungan bahan organik paling banyak ditemui pada lapisan $0-20 \mathrm{~cm}(15-20 \%)$, semakin ke bawah semakin berkurang. Hal itu disebabkan kerena akumulasi bahan organik terkonsentrasi di lapisan atas.

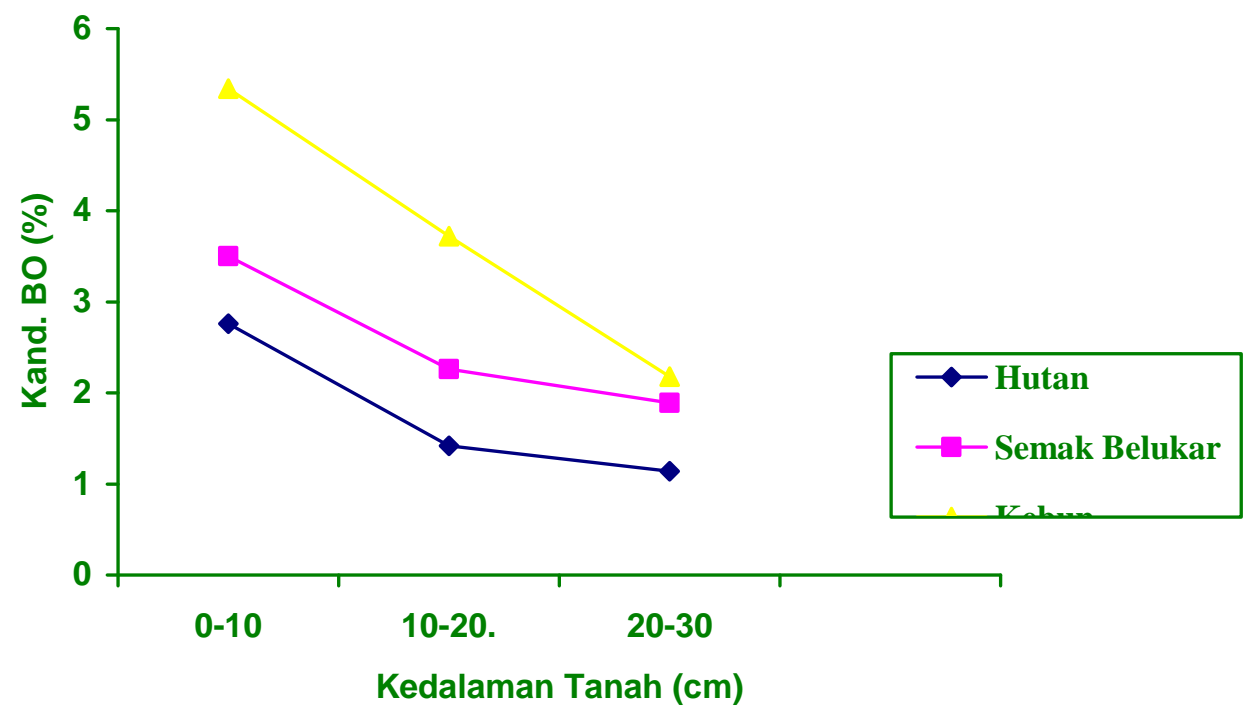

Gambar 4. Kandungan bahan organik pada beberapa penggunaan lahan di kawasan hutan hujan tropik Pinang Pinang 
Kandungan Bahan Organik Fraksi Berat (BO-FB) dan Fraksi Ringan (BO-FR)

Hasil analisis BO-FB $\left(\geq 1 \mathrm{gcm}^{-3}\right)$ dan BO-FR $\left(<1 \mathrm{gcm}^{-3}\right)$ ditampilkan pada Tabel 2. Bahan organik fraksi ringan dengan densitas $<1 \mathrm{gcm}^{-3}$ termasuk sangat ringan. Biasanya para peneliti menggunakan angka $1.6 \mathrm{gcm}^{-3}$ (Wang et al., 2003; Rovira dan Vallejo, 2003). Peningkatan densitas cairan pengklasifikasi meningkatkan jumlah BO-FR. Seperti yang ditemukan oleh Ladd dan Amato (1980) bahwa bagian dari berat tanah utuh dan bahan organik tanah fraksi ringan sangat sensitif terhadap fraksi densitas cairan. Pada densitas cairan 1,6 $\mathrm{gcm}^{-3}$ dihasilkan BO-FR 4 hingga 50 kali lebih rendah dibandingkan dengan densitas cair 2,0 $\mathrm{gcm}^{-3}$. Dengan densitas cairan $1,6 \mathrm{gcm}^{-3}$ bisa menghasilkan $\pm 1-9 \%$ karbon tanah dalam bentuk fraksi ringan, sementara dari cairan yang berdensitas 2,0 $\mathrm{gcm}^{-3}$ menghasilkan karbon mencapai $5-31 \%$.

Berdasarkan Tabel 2 terlihat bahwa diantara ketiga penggunaan lahan, kandungan BO-FB kebun campuran paling tinggi pada setiap kedalaman. Menurut kriteria kandungan bahan organik kedalaman $0-10 \mathrm{~cm}$ pada kebun campuran termasuk sedang, sedangkan pada lahan hutan dan semak belukar termasuk kriteria rendah dan sangat rendah. Bila dibandingkan dengan total bahan organik, persentase BO-FB cenderung meningkat dari lahan hutan (53\%), menjadi semak belukar $(78 \%)$ dan menjadi kebun campuran $(85 \%)$ pada kedalaman $0-10 \mathrm{~cm}$. Hal ini mungkin disebabkan karena rendahnya tingkat pelapukan bahan organik pada lahan hutan. Sehingga persentase bahan organik yang sudah terdekomposisi dan berasosiasi dengan bahan mineral tanah lebih rendah.

Seperti yang ditemukan untuk bahan organik total pada umumnya, kandungan bahan organik fraksi berat juga menurun dengan kedalaman. Pola penurunan kandungan bahan organik fraksi berat dari permukaan tanah sampai kedalaman $30 \mathrm{~cm}$ dapat dilihat pada Gambar 5.

Perubahan ini juga mencerminkan bahwa bahan organik lebih banyak berasal dari atas permukaan tanah dibandingkan dengan dari dalam tanah.

Tabel 2. Hasil analisis kandungan bahan organik fraksi berat $\left(>1,0 \mathrm{gcm}^{-3}\right)$.

\begin{tabular}{|c|c|c|c|}
\hline \multirow{2}{*}{$\begin{array}{l}\text { Penggunaan } \\
\text { Lahan }\end{array}$} & \multicolumn{3}{|c|}{ Kedalaman } \\
\hline & $0-10$ & $10-20$ & $20-30$ \\
\hline & -------------------------- & ----------\% --------- & |----------י \\
\hline \multicolumn{4}{|l|}{ BO-FB } \\
\hline Hutan & 52.5 & 72.5 & 81.6 \\
\hline Semak Belukar & 78.9 & 83.2 & 84.7 \\
\hline Kebun Campuran & 85.6 & 86.6 & 94.0 \\
\hline \multicolumn{4}{|l|}{ BO-FR } \\
\hline Hutan & 47.5 & 27.5 & 18.4 \\
\hline Semak Belukar & 21.1 & 16.8 & 15.3 \\
\hline Kebun Campuran & 14.4 & 13.4 & 6.0 \\
\hline
\end{tabular}




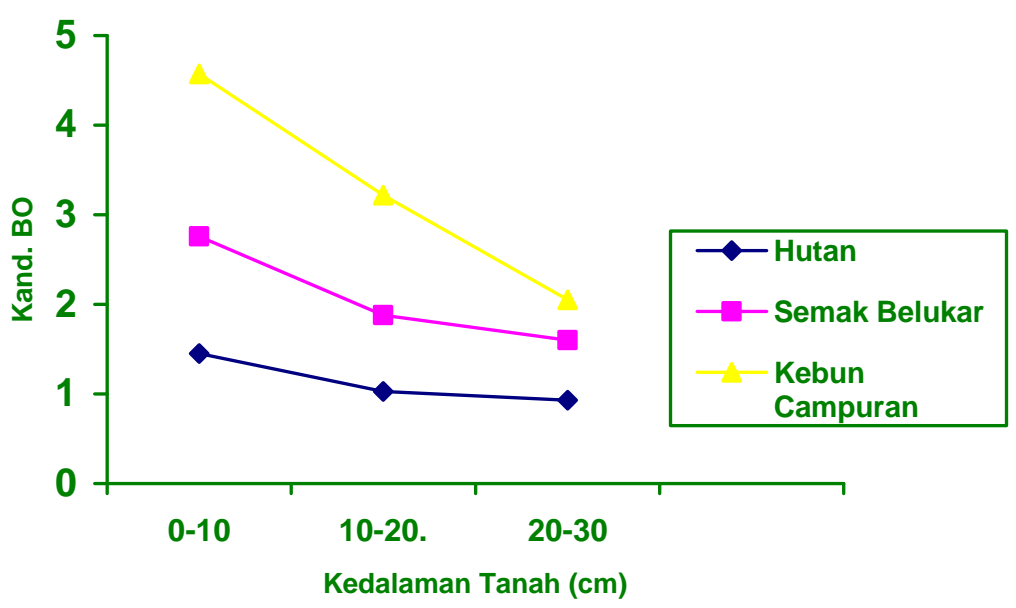

Gambar 5. Kandungan BO-FB (> 1,0 $\left.\mathrm{gcm}^{-3}\right)$ pada tiga penggunaan lahan di kawasan hutan hujan tropik Pinang Pinang

Hal ini dapat disebabkan oleh proses perombakan bahan organik di dalam tanah sangat lambat dibandingkan dengan di atas permukaan tanah, karena di dalam tanah kelembabannya lebih tinggi, ketersediaan oksigen berkurang, dan cahaya matahari tidak dapat masuk ke dalam tanah. Disamping itu, mikroorganisme perombak bahan organik tanah juga lebih banyak terdapat di permukaan tanah karena sumber makanannya lebih banyak tersedia.

Sebaliknya, kandungan BO-FR pada setiap penggunaan lahan termasuk pada kriteria sangat rendah, baik pada kedalaman
$0-10 \mathrm{~cm}, 10-20 \mathrm{~cm}$, maupun pada kedalaman $20-30 \mathrm{~cm}$. Akan tetapi, masih terlihat kecenderungan penurunan kandungan BO-FR dari permukaan sampai kedalaman $30 \mathrm{~cm}$ (Gambar 6). Pada lahan hutan BO-FR dibanding BO total menurun dari $37 \%(0-10 \mathrm{~cm})$ menjadi $17 \%(10-$ $20 \mathrm{~cm})$ dan mejadi $16 \%(20-30 \mathrm{~cm})$. Pada lahan semak belukar penurunannya tidak setajam pada lahan hutan. Kandungan BOFR semak belukar menurun dari $16 \%(0-$ $10 \mathrm{~cm})$ menjadi $14 \%(10-20 \mathrm{~cm})$ dan menjadi $8 \%(20-30 \mathrm{~cm})$.

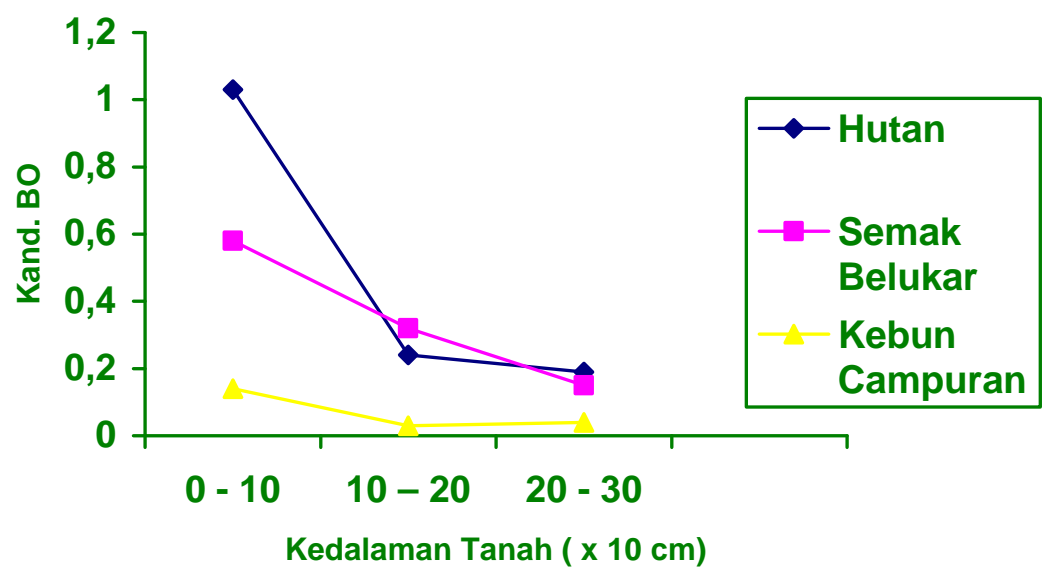

Gambar 6. Kandungan BO-FR $\left(<1,0 \mathrm{gcm}^{-3}\right)$ pada tiga penggunaan lahan di kawasan hutan hujan tropik Pinang Pinang 
Sedangkan pada lahan kebun campuran kandungan BO-FR nya menurun dari 2,6 \% $(0-10 \mathrm{~cm})$, menjadi $0,8 \%(10-20 \mathrm{~cm})$ dan meningkat menjadi $1,8 \%(20-30)$. Penurunan kandungan BO-FR pada suatu lahan sebanding dengan peningkatan kandunagn BO-FB nya

Rendahnya kandungan bahan organik fraksi ringan pada kebun campuran ini disebabkan oleh proses dekomposisi bahan organik pada lahan kebun campuran lebih cepat dibandingkan hutan dan semak belukar kemudian berasosiasi dengan bahan mineral membentuk fraksi berat. Ditemukan pada lahan ini, tingginya laju dekomposisi bahan organik pada lahan kebun campuran ini disamping disebabkan oleh suhu dan kelembaban tanah yang kondusif bagi aktifitas mikroba, juga disebabkan oleh tersedianya udara $\left(\mathrm{O}_{2}\right)$ yang cukup sampai kedalaman $30 \mathrm{~cm}$ karena tekstur tanahnya lebih kasar dari yang lain. (Yulnafatmawita et al,, $2007 \mathrm{~b}$ ).

\section{KESIMPULAN DAN SARAN}

Dari hasil survai dan analisis laboratorium yang dilakukan terhadap tanah pada tiga penggunaan lahan di daerah Bukit Pinang Pinang kawasan hutan hujan tropik Gunung Gadut Padang, maka dapat diambil kesimpulan sebagai berikut:

1. Pada setiap penggunaan lahan (hutan, semak belukar dan kebun campuran), kandungan bahan organik menurun dengan kedalaman, baik kandungan bahan organik tanah total, fraksi berat maupun fraksi ringan.

2. Perubahan penggunaan lahan dari hutan menjadi semak belukar dan kebun campuran dalam waktu yang lama (>20 tahunan) meningkatkan kandungan total dan kandungan BOFB tanah.

3. Kandungan bahan organik tanah meningkat dari $2,76 \%$ menjadi $3,5 \%$ dan $5,34 \%$ pada lapisan $0-10 \mathrm{~cm}$, dari $1,42 \%$ menjadi $2,26 \%$ dan
$3,72 \%$ pada lapisan $10-20 \mathrm{~cm}$, begitu juga dari $1,14 \%$ menjadi $1,6 \%$ dan $2,18 \%$ pada lapisan $20-$ $30 \mathrm{~cm}$, secara berturut-turut untuk hutan, semak belukar dan kebun campuran.

4. Kandungan BO-FB (densitas $\geq 1$ $\mathrm{gcm}^{-3}$ ) pada kedalaman $0-10 \mathrm{~cm}$ yaitu dari $1,45 \%, 2,76 \%$, dan $4,57 \%$, pada kedalaman $10-20 \mathrm{~cm}$ yaitu $1,03 \%, 1,88 \%$, dan $3,22 \%$, dan pada kedalaman $20-30 \mathrm{~cm}$ yaitu $0.93 \%, 1.6 \%$, dan $2.05 \%$, secara berturut-turut untuk hutan, semak belukar, dan kebun campuran.

5. Kandungan BO-FR (densitas < 1 $\mathrm{gcm}^{-3}$ ) pada kedalaman $0-10$ yaitu $1,31 \%, 0,74 \%$ dan, $0,77 \%$, pada kedalaman $10-20 \mathrm{~cm}$ yaitu $0,39 \%$, $0,38 \%$, dan $0,5 \%$, dan pada kedalaman $20-30 \mathrm{~cm}$ yaitu $0,21 \%$, $0,29 \%$, dan $0,13 \%$, secara berturutturut dari hutan, semak belukar, dan kebun campuran.

\section{DAFTAR PUSTAKA}

Aflizar. 2003. Sarasah dan karakteristik fisika dan unsur hara tanah hutan hujan tropis super basah di PinangPinang. Tesis Pasca Sarjana Pertanian Universitas Andalas. Padang. 141 hal.

Agus, F. , Noordwijk, M., dan Rahayu,S. 2004. Dampak Hidrologi Hutan Agroforestri dan Pertanian Lahan Kering Sebagai Dasar Pemberian Imbalan Kepada Penghasil Jasa Lingkungan di Indonesia. Prosiding Lokakarya Padang/Singkarak. Padang. 148 hal.

Allison, F. E. 1973. Soil organic matter and its role in crop production. Elsevier Scientific Publishing Company. Amsterdam London. New York. 637 pages

Aisyah. 1986. Perbandingan Sifat-sifat fisika tanah Andosol di Sumatera Barat. Thesis Fakultas Pertanian Universitas Andalas Padang. 
Arsyad, S. 2000. Konservasi tanah dan air. IPB Press. Bogor. 290 hal.

Burhanudin. 1979. Pengaruh beberapa sifat fisika tanah terhadap pengelolaan tanah, air, dan masalahnya di Sumatera Barat. Fakultas Pertanian Universitas Andalas. Padang. 47 hal.

Baver, L. D. , Gardener W.H., and Gardener, W.R. 1972. Soil physics. New York: Jhon Willey and Sons, Inc. 489 hal.

Christensen, B. T. 1992. Physical fraction of soil and organic matter in primary particle size and density separates. Springer-Verlag. New York. 88 pages

Daniel, T., Jhon, W., Helms, A., Fredrik, S., and Backer. 1995. Prinsip-prinsip silvikultur.(Terjemahan dari Principle of Silviculture). Gajah Mada University Press. Yogyakarta. 67 hal

Darmawidjaya, M. I. 1990. Klasifikasi tanah. Dasar Teori bagi Peneliti Tanah dan Perlaksanaan Pertanian di Indonesia. Gajah Mada University Press. Yogyakarta. 411 hal.

Departeman Pertanian Bogor. 2005. Teknologi pengelolaan lahan kering. 245 hal

Donahue, R. D. 1977. Soil Introduction to soil and plant growth. Fourth Edition Prentice Hall, Inc. Englewood. Cliffs. 626 p.

Ewusie, J. Y. 1990. Pengantar ekologi tropika. (terjemahan dari Element of Tropical Ecology). Penerbit ITB. Bandung.

Foth, H. D. 1998. Dasar-dasar ilmu tanah. Gajah Mada University Press. Yogyakarta. 782 hal.

Garwood, E. A. , Clement, C. R. , and Williams, T. E. 1972. Leys and organic matter III. The accumulation of macro-organic matter in the soil under different swards. J. Argic. Sci. Camb. 78: 333-341.
Hakim, N. , Nyakpa, M. Y. , Lubis, A. M. , Nugroho, S. G. , Diha, M. A. , Hong, G. B. , and Bailey,H. H. 1986. Dasar-dasar ilmu tanah. Penerbit Universitas Lampung. Lampung. 488 hal

Hairiah, K. dan Noorwidjak, M.V. 2004. Pengelolaan tanah masam secara biologi. Internationa Centre for Research in Agroforestry. Bogor.216 hal.

Hardjowigeno, S. 2003. Ilmu tanah. Akademik Pressindo. Jakarta. 286 hal.

Haridjaja, O. 1980. Pengantar fisika tanah. Institut Pendidikan Latihan dan Penyuluhan Pertanian. IPB. Bogor. 70 hal.

Hermansah. 2002. Micro Spatial Distribution Pattern pf Litter Fall and Nutrient Fluxin Relation to Soil Chemistry Properties in Super Wet Tropical Rain Forest West Sumatera. Indonesia Tropic 12 (2)pp. 131-146

Hillel, D. 1980. Soil and water, physical and principle processes. New York: Academic Press. 413 hal.

Imam, T. 2003. Perubahan tahanan geser dan tahanan gesek tanah pada berbagai jenis dan dosis bahan organik. Fakultas Teknologi Pertanian. IPB. Bogor. 108 hal.

Islami, T. dan Utomo, W. H. 1995. Hubungan tanah, air dan tanaman. IKIP Semarang Press. Semarang. 297 hal.

Jastrow, J. D. 1996. Soil Aggragate Formatin and The Accrual of Particulate and Mineral-Associated Organic Matter. Soil Biol. Biochem., 28 (4/5): 665-676.

Lembaga Penelitian Tanah. 1979. Penuntun analisis fisika tanah. Departemen Ilmu tanah Badan Penelitian dan Pengembangan Pertanian. Bogor. 47 hal.

Luki, U. 1995. Dasar-dasar fisika tanah terapan. Jurusan Tanah Fakultas 
Pertanian Universitas Anadalas. Padang. 125 hal.

Richards, P. W. 1964. The tropical rain forest and ecological study. Cambridge University Press. Philipine. 15 hal

Rovira, P and Vallejo, V.R. 2003. Physical $\mathrm{p}$ [rotection and biochemical quality of organic matter in mediterranean calcareous forest soils: a density fractionation approach. Soil Biol. Biochem., 35(2):245-261

Sarief, S. 1980. Fisika tanah dasar. Serial publikasi ilmu-ilmu tanah. Fakultas Pertanian. Universitas Padjajaran. Bandung. 120 hal.

Six, J., Elliot, E.T., Paustian, K., and Doran, J.W. 1998. Aggregation and Soil Organik Matter Accumulation in Cultivated and Native Grassland Soil. Soil Sci. Soc. Am. J., 62 (5), 1367-1377.

Soegiman. 1982. Ilmu tanah. Terjemahan Buckman and Brady "The Nature and Properties of Soil" Bhratara Karya Aksara. Jakarta.

Soepardi, G. 1983. Sifat dan ciri tanah. Jurusan Ilmu Tanah, Fakultas Pertanian. Institut Pertanian Bogor. Bogor. 591 hal.

Soerianegara, I. dan Indrawan, A. 1998. Ekologi Hutan Indonesia. Jurusan Manajemen Htuan. Fakultas Kehutanan Bogor.13. 16-29

Syarbaini, M. 1987. Karakteristik Sub DAS Batang Arau I Kotamadya Padang Sumatra Barat. Tesis. Fakultas Pasca Sarjana IPB. Bogor. 125 hal.

Wesley, L. D. 1973. Mekanika tanah. Jakarta: Badan Penelitian Pekerjaan Umum. 165 hal.

Wakatsuki, T., Saidi, A. , dan Rasyidin, A. 1986. Soil in Toposequense of the Gunung Gadut Tropical Rain Forest, West Sumatra. Depertmen of Soil Science Faculty of Agriculture. Andalas University. Padang. 243261 hal
Yulnafatmawita. 2004. Effect of Land Use Change on Soil Organic Matter Status of Bulk and Fractionated Soil Aggregates. Stigma Science Journal Volume XII (2). 10 hal

Yunafatmawita. 2005a. Susceptibility of Fractionated Soil Organic Matter. Prosiding SEMIRATA Dosen BKS-PTN. Padang. 14 hal

Yulnafatmawita. 2005b. Fractionation of Soil Based on Bonding Energy and Aggregate Size: a method for studying the effect of structural hierarchy on degradation process. Disertation Univerity of Queensland Australia. 214 pages

Yulnafatmawita. 2006a. Penuntun pratikum fisika tanah. Universitas Andalas Padang. 85 hal.

Yulnafatmawita. 2006b. Hubungan antara Status C-Organik dan Stabilitas Agregat Tanah Ultisol Limau Manis Padang Akibat Perubahan Penggunaan Lahan. Prosiding Seminar Tahunan Dosen BKS-PTN. Jambi. 20 hal.

Yulnafatmawita, Luki, U., dan Afriyana. 2007a. Kajian Sifat Fisika Tanah Beberapa Penggunaan Lahan Di Bukit Gajabuih, Kawasan Hutan Hujan Tropis Gunung Gadut Padang. Prosiding SEMIRATA Dosen BKSPTN. UNRI. Pekan Baru. 15 hal.

Yulnafatmawita, Saidi, A., dan Hermansah. 2007b. Distribusi Vertikal Bahan Organik Tanah Pada Bukit Pinang Pinang Kawasan Hutan Hujan Tropik Gunung Gadut Padang. Makalah Disampaikan Pada Kongres HITI ke IX 5 - 7 Desember 2007 di Yogyakarta. 